\title{
PENGARUH WAKTU EKSTRAKSI TERHADAP TOTAL FENOLAT DAN NILAI IC50 DARI EKSTRAKSI KULIT BUAH NAGA MERAH (Hylocereus polyrhizus)
}

\section{EXTRACTION TIME AS IMPACT ON TOTAL PHENOLATE AND IC50 VALUE FROM RED DRAGON FRUIT SKIN EXTRACTION (Hylocereus polyrhizus)}

\author{
Amalia Noviyanty ${ }^{*}$, Chitra Anggriani Salingkat ${ }^{1}$, Syamsiar $^{1}$ \\ ${ }^{1}$ Program Studi Agroteknologi, Fakultas Pertanian, Universitas Tadulako, \\ Jln. Soekarno-Hatta Km.9 Palu 94118 Sulawesi Tengah Indonesia
}

\begin{abstract}
ABSTRAK
Kulit dari buah naga merah merupakan limbah yang masih sangat jarang dimanfaatkan. Sementara persentase kulit buah naga merah adalah 30\% hingga 35\% dari berat buahnya. Kulit buah naga masih mengandung senyawa antioksidan yang cukup tinggi, senyawa antioksidan mampu melawan oksidasi dalam tubuh. Pemanfaatan dilakukan pada kulit buah naga salah satunya adalah dengan mengekstraknya sehingga dapat dimanfaatkan sebagai bahan dasar beragam pangan fungsional yang akan bermanfaat bagi kesehatan. Penelitian bertujuan untuk mengetahui pengaruh waktu ekstraksi terhadap total fenolat dan aktivitas antioksidan (nilai IC50) pada ekstrak kulit buah naga merah dan juga memperoleh waktu ekstraksi yang optimum untuk mendapatkan total fenol dan nilai IC50 tertinggi atau terbaik. Waktu ekstraksi yang digunakan terdiri atas 3 level yaitu 24 jam (1 hari), 48 jam (2 hari) dan 72 jam (3 hari). Data yang diperoleh dianalisis menggunakan Rancangan Acak Lengkap yang diterapkan pada pengamatan total fenolat dan nilai IC50, jika perlakuan berpengaruh sangat nyata atau nyata dilanjutkan uji lanjut BNJ pada taraf $1 \%$ atau $5 \%$. Hasil penelitian menunjukkan bahwa waktu ekstraksi berpengaruh sangat nyata terhadap total fenolat dan nilai IC50 ekstrak kulit buah naga dan waktu ekstraksi 3 jam memberikan total fenolat dan nilai IC50 tertinggi atau terbaik yaitu 78,78 ppm dan 115,90 ppm.
\end{abstract}

Kata kunci: kulit buah naga merah; waktu ekstraksi; total fenolat; nilai IC50

\begin{abstract}
The skin of the red dragon fruit is a waste that is still very rarely used. While the percentage of red dragon fruit skin is $30 \%$ to $35 \%$ of the weight of the fruit. Dragon fruit peels still contain quite high antioxidant compounds, antioxidant compounds can fight oxidation in the body. Utilization is done on the skin of dragon fruit, one of which is to extract it so that it can be used as a basis for a variety of functional foods that will benefit health. The study aims to determine the effect of extraction time on total phenolics and antioxidant activity (IC50 values) on red dragon fruit peel extracts and also obtain the optimum extraction time to get the highest or best total phenol and IC50 values. Extraction time used consists of 3 levels, namely 24 hours (1 day), 48 hours (2 days) and 72 hours (3 days). The data obtained were analyzed using the Completely Randomized Design which was applied to the observation of total phenolics and IC50 values, if the treatment had a very significant or real effect followed by continued BNJ testing at $1 \%$ or $5 \%$ level. The results showed that the extraction time had a very significant effect on the total phenolics and IC50 values of dragon fruit peel extract and the extraction time of 3 hours gave the highest or best total phenolics and IC50 values of 78.78 ppm and $115.90 \mathrm{ppm}$.
\end{abstract}

Keywords: red dragon fruit skin; extraction time; total phenolics; IC50 value

\footnotetext{
${ }^{*}$ Penulis Korespondensi

E-mail : amalianoviyanti@ymail.com

Telp: 085241237506
} 


\section{Pendahuluan}

Kulit dari buah naga merah merupakan limbah yang masih sangat jarang dimanfaatkan. Sementara persentase kulit buah naga merah adalah 30\% hingga 35\% dari berat buahnya (Santoso dan Fibrianto, 2017). Limbah kulit buah naga dapat bermanfaat sebagai pewarna alami dalam produksi pangan, industri maupun bidang farmakologi. Kulit buah naga masih mengandung senyawa antioksidan yang cukup tinggi, senyawa antioksidan mampu melawan oksidasi dalam tubuh. Jika tingkat oksidasi dalam tubuh meningkat akan menyebabkan kerusakan DNA, sehingga risiko terjadinya kanker juga akan meningkat (Wisesa dan Widjanarko, 2014).

Pemanfaatan yang dapat dilakukan pada kulit buah naga salah satunya adalah dengan mengekstraknya sehingga dapat dimanfaatkan sebagai bahan dasar beragam pangan fungsional yang akan bermanfaat bagi kesehatan. Menurut Yuswi, 2017), senyawa aktif yang terkandung dalam tanaman dapat dipisahkan dengan proses ekstraksi. Beberapa faktor yang menentukan kualitas hasil ekstraksi salah satunya adalah waktu ekstraksi (Wati, dkk., 2017).

Terlalu singkatnya waktu ekstraksi mengakibatkan pelarutan senyawa fenolik tidak optimum sehingga bahan belum terekstraksi secara sempurna dan sebaliknya, semakin lama waktu ekstraksi maka akan menaikan jumlah analit yang terekstrak karena kontak antara pelarut dengan zat terlarut akan semakin lama sehingga proses pelarutan senyawa fenolik akan terus berlangsung dan berhenti sampai pelarut jenuh. Namun, ketika waktu optimum telah tercapai, penambahan waktu ekstraksi tidak lagi dapat meningkatkan kandungan senyawa fenolik yang terekstrak (Kristanti, dkk., 2019).

Sejauh ini penelitian tentang ekstraksi kulit buah naga telah beberapa kali dilakukan, diantaranya Wisesa dan Widjanarko (2014) tentang ekstraksi kulit buah naga merah, yang memperoleh hasil yaitu suhu dan waktu ekstraksi maksimum untuk respon aktivitas antioksidan sebesar $58.40^{\circ} \mathrm{C}$ dan 28 menit yang menghasilkan aktivitas sebesar $15.90 \%$, untuk respon total fenol sebesar $58.10^{\circ} \mathrm{C}$ dan 25 menit yang menghasilkan nilai sebesar $54.66 \mathrm{mg} / \mathrm{L}$ dan untuk respon warna (nilai b) sebesar $56.90^{\circ} \mathrm{C}$ dan 28 menit yang menghasilkan nilai -0.2. Tetapi belum ditemukan informasi tentang waktu ekstraksi yang optimum (hari) untuk mengekstrak kulit buah naga. Berdasarkan hal tersebut diatas, penelitian ini bertujuan untuk mengetahui pengaruh waktu ekstraksi terhadap total fenolat dan aktivitas antioksidan (nilai IC50) pada ekstrak kulit buah naga merah dan juga memperoleh waktu ekstraksi yang optimum untuk mendapatkan total fenol aktivitas antioksidan tertinggi atau terbaik.

\section{Metode Penelitian}

\section{Bahan dan Alat}

Bahan utama yang digunakan yaitu kulit buah naga merah yang berasal dari Pasar Tradisional Inpres Manonda, sedangkan bahan penunjang yang digunakan yaitu etanol 95\%, asam galat, reagen Folin Ciocalteu, larutan $\mathrm{Na} 2 \mathrm{CO} 320 \%$ dan larutan DPPH 50 $\mu \mathrm{M}$.

Peralatan yang digunakan adalah timbangan biasa,timbangan analitik, kertas saring, blender, penangas air, erlenmeyer, labu ukur alas bulat yang dilengkapi dengan pendingin balik, rotary evaporator, tabung reaksi, mesin pengocok (shaker), gas N2, spektrofotometer UV-VIS, pipet tetes.

\section{Pelaksanaan Penelitian \\ Rancangan Penelitian}

Penelitian ini adalah penelitian eksperimental dan penelitian ini dirancang menggunakan Rancangan Acak Lengkap (RAL) atau analisa of varian (ANOVA) yaitu untuk perlakuan waktu ekstraksi dengan 3 tingkatan waktu (24 jam, 48 jam dan 72 jam) yang semua perlakuan tersebut diulang sebanyak 3 kali sehingga terdapat 9 unit percobaan. Data yang diperoleh akan dianalisis dengan analisis varian, apabila terdapat perbedaan/pengaruh sangat nyata atau nyata antar perlakuan maka akan dilanjutkan dengan uji BNJ pada taraf signifikasi $1 \%$ atau $5 \%$.

\section{Prosedur Penelitian}

\section{Persiapan Kulit Buah Naga Merah}

Kulit buah naga merah yang diperoleh ditimbang, diiris halus, dikeringkan dan dibuat menjadi tepung dengan menggunakan blender, kemudian siap untuk digunakan pada penelitian selanjutnya.

\section{Persiapan Ekstrak Kulit Buah Naga}

Tahap ini dilakukan dengan cara kulit buah naga merah bentuk tepung ditimbang sebanyak $50 \mathrm{~g}$, kemudian dimasukkan ke dalam erlenmeyer $500 \mathrm{ml}$, selanjutnya ditambahkan pelarut etanol 95\% $250 \mathrm{ml}$. Campuran dikocok di atas mesin kocok (shaker) aqitasi 200 rpm sesuai perlakuan 
waktu ekstraksi (1 hari (24 jam), 2 hari (48 jam) dan 3 hari (72 jam). Campuran disaring, filtrat atau ekstrak yang dihasilkan diuapkan pelarutnya secara vakum dengan alat rotari vakum evaporator. Penguapan pelarut disempurnakan dengan gas nitrogen. Ekstrak selanjutnya ditimbang untuk mengetahui rendemannya, ditentukan aktivitas antioksidannya dan ditentukan total fenolatnya. Waktu ekstraksi yang menghasilkan ekstrak yang memiliki total fenolat dan aktivitas antioksidan tinggi atau terbaik dinyatakan sebagai waktu ekstraksi terseleksi.

\section{Definisi Operasional Variabel dan Pengukurannya}

\section{Penentuan Total Fenolat}

a. Pembuatan Kurva Kalibrasi Asam Galat Dengan Reagen Folin-Ciocalteu.

Asam galat ditimbang $25 \mathrm{mg}$ dan ditambahkan etanol 96\% : air (1:1) sampai volume $25 \mathrm{ml}$. Dari larutan induk $1000 \mathrm{mg} / \mathrm{l}$ dibuat seri pengenceran $20,40,60,80,100$, dan $120 \mathrm{mg} / \mathrm{l}$ asam galat. Dari masing-masing konsentrasi di atas dipipet $1 \mathrm{ml}$ dan ditambahkan $10 \mathrm{ml}$ aquadest, kemudian ditambah $1 \mathrm{ml}$ Reagen Folin Ciocalteu dan dikocok. Larutan didiamkan selama 8 menit, ditambahkan $3 \mathrm{ml}$ larutan Na2CO3 20\%, dikocok homogen. Didiamkan selama 2 jam pada suhu kamar. Diukur serapan pada panjang gelombang maksimum yang diperoleh, kemudian dibuat kurva kalibrasi hubungan antara konsentrasi asam galat $(\mathrm{mg} / \mathrm{l})$ dengan absorban.

b. Penentuan Kandungan Total Fenolik dengan Metode Folin Ciocalteu.

Ekstrak pekat ditimbang 0,025 $\mathrm{mg}$ dan dilarutkan sampai $25 \mathrm{ml}$ dengan etanol : air (1 : 1). Larutan dipipet $1 \mathrm{ml}$, ditambah dengan $10 \mathrm{ml}$ aquadest dan $1 \mathrm{ml}$ reagen Folin Ciocalteu dan dikocok. Larutan didiamkan selama 8 menit, ditambah $3 \mathrm{ml} \mathrm{Na} 2 \mathrm{CO} 320 \%$, kemudian didiamkan selama 2 jam pada suhu kamar. Setelah itu diukur serapannya dengan spektrofotometer UV-Vis pada panjang gelombang maksimum yang diperoleh. Total fenolat sampel ditentukan dengan rumus:

Total Fenolik $(\%)=\frac{x\left(\frac{m g}{\mathrm{~L}}\right) \mathrm{x} \text { ol.sampel }(\mathrm{L}) \mathrm{X} \text { FP }}{\text { Bobot sampel }(\mathrm{mg})} \mathrm{X} 100 \%$

\section{Penentuan Aktivitas Antioksidan dengan Metode DPPH (IC50)}

Ekstrak pekat sampel ditentukan aktivitas antioksidannya menggunakan metode spektrofotometri dengan pereaksi DPPH. Ekstrak sampel ditimbang sebanyak $25 \mathrm{mg}$, dimasukkan ke dalam labu ukur $25 \mathrm{ml}$, kemudian diencerkan dengan pelarut etanol sehingga didapatkan konsentrasi larutan $1000 \mathrm{ppm}$. Setelah itu dilakukan seri pengenceran untuk mendapatkan larutan 10, 30, 50, 70 dan 90 ppm. Larutan yang telah dibuat dipipet sebanyak $0,2 \mathrm{ml}$ dan ditambahkan dengan 3,8 ml larutan DPPH 50 $\mu \mathrm{M}$. Campuran dihomogenkan dan dibiarkan selama 30 menit dalam tempat gelap. Kemudian diukur serapannya pada panjang gelombang $517 \mathrm{~nm}$. Pengujian juga dilakukan terhadap larutan DPPH. Nilai absorbansi yang diperoleh digunakan untuk menentukan \% inhibisi dengan rumus berikut:

$$
\% \text { Inhibisi }=\frac{\text { Abs. DPPH }- \text { Abs. Sampel }}{\text { Abs. DPPH }} \times 100 \%
$$

Selanjutnya, dibuat kurva $\%$ inhibisi dan ditentukan IC50 berdasarkan persamaan regresi yang diperoleh.

\section{Hasil dan Pembahasan}

Waktu ekstraksi memiliki pengaruh yang besar terhadap ekstraksi, terlalu lama atau terlalu singkat waktu ekstraksi dapat mempengaruhi sifat fisik dan kimia dari bahan yang terekstrak (Sari, $d k k .$, 2013).

\section{Total Fenolat}

Fenol merupakan senyawa yang banyak ditemukan pada tumbuhan. Fenolik memiliki cincin aromatik dengan satu atau lebih gugus hidroksil (OH-) dan gugus-gugus lain penyertanya. Senyawa fenolik kebanyakan memiliki gugus hidroksil lebih dari satu sehingga disebut polifenol (Lestari, $d k k .$, 2014).

Hasil analisis ragam menunjukkan bahwa perlakuan waktu ekstraksi memberikan pengaruh sangat nyata terhadap total fenolat ekstrak kulit buah naga. Hasil analisis uji lanjut BNJ $1 \%$ dan rerata total fenolat ekstrak kulit buah naga pada perlakuan waktu ekstraksi dapat dilihat pada Gambar 9.

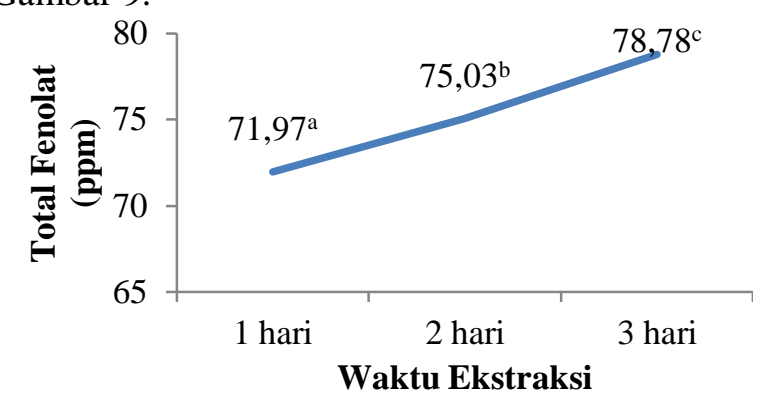

Gambar 1. Rerata Total Fenolat (ppm) Kulit Buah Naga Pada Perlakuan Waktu Ekstraksi.

**Keterangan: huruf yang berbeda pada kolom yang sama menunjukkan perbedaan yang nyata pada uji BNJ taraf $1 \%$. 
Gambar 1 menunjukkan bahwa total fenolat ekstrak tertinggi dihasilkan pada perlakuan waktu ekstraksi 3 hari yaitu 78,78 ppm yang berbeda dengan perlakuan waktu ekstraksi lainnya pada uji lanjut BNJ $1 \%$, sedangkan rendemen ekstrak terendah dihasilkan pada perlakuan waktu ekstraksi yaitu 1 hari yaitu $71,97 \%$ yang berbeda dengan perlakuan waktu ekstraksi lainnya pada uji lanjut BNJ $1 \%$.

Hasil penelitian menunjukkan (Gambar 1) bahwa peningkatan waktu ekstraksi sampai 3 hari meningkatkan kandungan senyawa total fenolat kulit buah naga. Hal tersebut memberikan keterangan kelarutan senyawa fenolat dalam kulit buah naga meningkat dengan meningkatnya penggunaan waktu ekstraksi yang meningkat. Hal ini sesuai dengan hasil penelitian Yuswi (2017) bahwa pengaturan waktu pada proses ekstraksi akan mempengaruhi hasil dari ekstraksi itu sendiri. dimana adanya pengaturan waktu untuk ekstraksi juga menyebabkan kontak kontak antara bahan dengan pelarut juga semakin lama Hal ini menyababkan pelarut mampu mengeluarkan senyawa dalam bahan lebih banyak.

\section{Aktivitas Antioksidan (Nilai IC50)}

Aktivitas antioksidan diukur dengan cara melihat kemampuan peredaman DPPH oleh ekstrak, yang disebut juga sebagi persen inhibisi. Parameter yang digunakan untuk menunjukkan aktivitas antioksidan adalah inhibition concentration (IC 50). Penentuan IC50 masing masing ekstrak bertujuan untuk memporoleh jumlah dosis ekstrak yang dapat meredam radikal bebas sebesar 50\% (Munte, $d k k$., 2015). Novita, dkk (2016) menyatakan bahwa nilai IC50 yang lebih kecil menunjukkan aktivitas antioksidan yang lebih tinggi.

Pengaruh waktu ekstraksi terhadap nilai IC50 ekstrak kulit buah naga dapat diketahui dengan melakukan analisis ragam. Hasil analisis ragam menunjukkan bahwa perlakuan waktu ekstraksi memberikan pengaruh sangat nyata terhadap nilai IC50 ekstrak kulit buah naga. Hasil analisis uji lanjut BNJ 1\% dan rerata nilai IC50 ekstrak kulit buah naga pada perlakuan waktu ekstraksi dapat dilihat pada Gambar 2.

Gambar 2 menunjukkan bahwa nilai IC50 tertinggi dihasilkan pada perlakuan waktu ekstraksi 3 hari yaitu 115,90 ppm yang berbeda dengan perlakuan waktu ekstraksi lainnya pada uji lanjut BNJ 1\%, sedangkan nilai IC50 terendah dihasilkan pada perlakuan waktu ekstraksi yaitu 1 hari yaitu 121,90 ppm yang berbeda dengan perlakuan waktu ekstraksi lainnya pada uji lanjut BNJ $1 \%$.

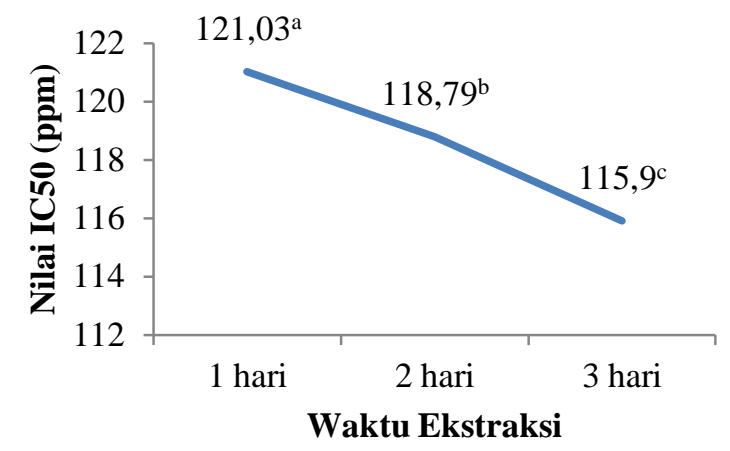

Gambar 2. Rerata Total Fenolat (ppm) Kulit Buah Naga Pada Perlakuan Waktu Ekstraksi.

**Keterangan : huruf yang berbeda pada kolom yang sama menunjukkan perbedaan yang nyata pada uji BNJ taraf $1 \%$.

Menurut Molyneux (2004) pada penelitiannya menyatakan bahwa aktivitas antioksidan diukur dari nilai IC50, yang dinyatakan pada Tabel 1. Nilai IC50 berbanding terbalik dengan aktivitas antioksidan. Semakin rendah nilai IC50 maka akan semakin baik aktivitas antioksidannya.

Tabel 1. Nilai IC50 terhadap aktivitas antioksidan

\begin{tabular}{l|l}
\hline Aktivitas Antioksidan & Nilai IC50 (ppm) \\
\hline Sangat Kuat & $<50$ \\
Kuat & $50-100$ \\
Sedang & $100-200$ \\
Lemah & $>200$ \\
\hline
\end{tabular}

Berdasarkan penggolongan kekuatan aktivitas antioksidan (Molyneux, 2004), waktu ekstraksi 1 hari sampai 3 hari memiliki aktivitas antioksidan yang sedang karena diperoleh nilai IC50 100 - 200 ppm. Menurut Agutina, dkk (2017) bahwa aktivitas antioksidan terjadi karena bereaksinya molekul difenil pikri hirazil dengan atom hidro-gen dari anti oksidan sehingga terbentuk senyawa difenil pikril hidrazin, yang terlihat terjadinya per-ubahan warna DPPH dari ungu menjadi kuning. Suatu senyawa dikatakan memiliki aktivitas antioksidan yang baik apabila nilai IC50 kurang dari 200 ppm. Apabila suatu senyawa memiliki nilai IC50 di atas 200 ppm sampai 1.000 ppm maka dapat dinyatakan bahwa senyawa tersebut masih memiliki potensi sebagai antioksidan, namun aktivitasnya kurang baik (Widianingsih, 2016).

Perbedaan nilai IC50 ini dapat disebabkan oleh jumlah antioksidan yang terkandung didalam ekstrak. Hal ini terjadi menurut Wahyuni dan Widjanarko, 2015 karena semakin lamanya waktu ekstraksi maka terjadinya kontak antara 
pelarut dengan bahan akan semakin lama sehingga dari keduanya akan terjadi pengendapan massa secara difusi sampai terjadi keseimbangan konsentrasi larutan di dalam dan diluar bahan ekstraksi.

Aktivitas antioksidan berbanding lurus dengan total fenol, semakin tinggi kandungan fenol dalam suatu bahan semakin tinggi pula aktivitasnya sebagai antioksidan (Huliselan, $d k k$., 2015). Hal ini sesuai dengan hasil yang diperoleh dimana penggunaan konsentrasi pelarut etanol 95\% memiliki kandungan total fenolik yang lebih tinggi dibandingkan dengan konsentrasi pelarut etanol $75 \%$ dan

Kestabilan antioksidan dapat dipengaruhi oleh faktor-faktor yakni suhu, perubahan $\mathrm{pH}$, sinar dan oksigen, serta faktor lainnya seperti ion logam. Selain itu, proses analisis tidak langsung dilakukan saat ekstrak kental telah siap, sehingga kondisi dan masa penyimpanan sampel menyebabkan senyawa fenol yang diduga terdapat didalamnya mengalami degradasi. Selain itu, adapula faktor yang mempengaruhi zat aktif pada tanaman, yaitu kandungan unsur hara pada tanaman (Sari dan Ayati, 2018).

\section{Kesimpulan dan Saran}

\section{Kesimpulan}

Berdasarkan hasil penelitian yang telah dilakukan maka dapat disimpulkan sebagai berikut:

1. Waktu ekstraksi berpengaruh sangat nyata terhadap total fenolat dan nilai IC50 ekstrak kulit buah naga merah

2. Waktu ekstraksi 3 hari merupakan waktu ekstraksi terbaik untuk mengekstrak kulit buah naga merah karena memiliki total fenolat $(78,78$ ppm $)$ dan aktivitas antioksidan (nilai IC50) $(115,90 \quad \mathrm{ppm})$ tertinggi atau terbaik.

\section{Saran}

Saran-saran yang dapat dikemukakan dari hasil penelitian yang telah dilakukan adalah:

1. Sebaiknya untuk mengekstraksi kulit buah naga menggunakan waktu ekstraksi 3 hari.

2. Perlu adanya penelitian lebih lanjut mengenai penambahan perlakuan waktu ekstraksi (jam) untuk lebih mengetahui pengaruh waktu ekstraksi terhadap mutu ekstrak yang dihasilkan

\section{Daftar Pustaka}

Agustina, W., Nurhamidah \& Handayani, D. 2017. Skrining fitokimia dan aktivitas antioksidan beberapa fraksidari kulit batang jarak (Ricinus communis L.). ALOTROP Jurnal Pendidikan dan Ilmu Kimia. 1(2) : 117-122.

Huliselan, Y. M., Max, R. J., Runtuwene \& Wewengkang, D. S. 2015. Aktivitas antioksidan ekstrak etanol, etil asetat, dan n-heksan dari daun sesewanua ( Clerodendron squamatum Vahl.). Pharmacon Jurnal Ilmiah Farmasi, 4(3).

Kristanti, Y., Widarta, I. W. R \& Permana, I. D. G. M. 2019. Pengaruh waktu ekstraksi dan konsentrasi etanol menggunakan metode Microwave Assisted Extraction (MAE) terhadap aktivitas antioksidan ekstrak rambut jagung (Zea mays L.). Jurnal Ilmu dan Teknologi Pangan. 8(1): 94-103.

Lestari, P. P., Kusrini. D. \& Anam, K. 2014. Anthocyanin identification of methanol-hcl extract active fraction in rosella (Hibiscus sabdariffa L.) and its potential as xanthine oxidase inhibitor. Jurnal Sains dan Matematika. 22(3): 72-78.

Molyneux, P. 2004. The use of the stable free radikal diphenyl picrylhydrazyl (DPPH) for estimating antioxidant activity. Journal Science of Technology. 26(2): 211-219.

Munte, L., Runtuwene, M. R \& Citraningtyas, G. 2015. Aktivitas antioksidan dari ekstrak daun prasman (Eupatorium triplinerve Vahl.). Pharmacon Jurnal Ilmiah Farmasi. 4(3).

Novita, M., Sulaiman, M. I \& Yura, S. 2016. Pengaruh jenis pelarut terhadap aktivitas antioksidan dan kandungan fenol beberapa jenis bayam dan sayuran lain. Jurnal Ilmiah Mahasiswa Pertanian Unsyiah. 1(1).

Santoso, A. F \& Fibrianto, K. 2017. Pengaruh ekstrak kulit buah naga merah (Hylocereus polyrhizus) terhadap kualitas sosis ayam: tinjauan pustaka. Jurnal Pangan dan Agroindustri. 5(4): 92-96.

Sari, A. K. \& Ayati, R. 2018. Penentuan aktivitas antioksidan ekstrak etanol daun jeruk purut (Citrus Hystrix D.C) dengan metode DPPH (1,1-diphenyl-2-picrylhydrazyl). Journal Current Pharmateutical Science (JCPS). 1(2): 69-74. 
Sari, K.. D., Wardhani, D. H \& Prasetyaningrum, A. 2013. Kajian isolasi senyawa fenolik rumput laut Euceuma cottonii berbantu gelombang micro dengan variasi suhu dan waktu. Jurnal Teknik Kimia. 3(19): 38-43.

Wahyuni, D. T \& Widjanarko, S. B. 2015. Pengaruh jenis pelarut dan lama ekstraksi terhadap ekstrak karotenoid labu kuning dengan metode gelombang ultrasonik. Jurnal Pangan dan Agroindustri. 3(2): 390-401.

Wati, I., Musadi, M. R., Khumaira, N. S \& Amelia, A. R. 2017. Pengaruh konsentrasi pelarut, waktu ekstraksi, dan nisbah bahan baku dengan pelarut terhadap ekstraksi kunyit kuning (Curcuma longa L.). Jurnal ITEKIMA. 2(1).
Widianingsih, M. 2016. Aktivitas antioksidan ekstrak metanol buah naga merah (Hylocereus polyrhizus (F.A.C Weber) Britton \& Rose) hasil maserasi dan dipekatkan dengan kering angin. Jurnal Wiyata. 3(2): 146-150.

Wisesa, T. B \& Widjanarko, S. B. 2014. Penentuan nilai maksimum proses ekstraksi kulit buah naga merah (Hylocereus polyrhizus). Jurnal Pangan dan Agroindustri. 2(3): 88-97.

Yuswi, N. C. R. 2017. Ekstraksi antioksidan bawang dayak (Eleutherine palmifolia) dengan metode ultrasonic bath (studi jenis pelarut dan lama ekstraksi). Jurnal Pangan dan Agroindustri. 5(1): 71-79. 